\title{
A New Historical Approach to John Donne's A Valediction: Forbidding Mourning
}

\author{
Pooyan Changizi \\ Parvin Ghasemi \\ Department of Foreign Languages and Linguistics, Faculty of Humanities and \\ Literature, Shiraz University, Eram Campus, Eram Street 7194684795, Shiraz, Iran \\ e-mails: pooyan_us2000@yahoo.com \\ pghasemi2000@yahoo.com; pghasemi54@gmail.com
}

\begin{abstract}
A Valediction: Forbidding Mourning is one of John Donne's most celebrated and most significant poems in which he declares, quite ingeniously, his ideal of spiritual love which transcends the ordinary and inferior love of others that is based on mere physicality. This essay applies New Historicism, a school of literary theory since the early 1980s, to Donne's seventeenth-century poem. The study begins with elaborating on the major concepts and principles of New Historicism. Then, the historical, cultural and biographical circumstances that surrounded and motivated the composition of Donne's poem are discussed. Finally, the discourses of religion, science, love, sexuality, space and time and the circulation of power implicit in the compass imagery, the metaphysical conceit used in this poem, are explored.
\end{abstract}

Key words: New Historicism, discourse, culture, religion, science, love, sexuality, power

New Historicism is an approach in literary theory that considers literary works as historical documents and cultural artifacts. It examines the circulation of power by studying the discourses present in the works of art. It starts from the premise that these discourses both shaped, and were shaped by the culture in which the art works appeared. New Historicist principles can be aptly applied to the study of John Donne's poem $A$ Valediction: Forbidding Mourning. This paper will discuss the historical and biographical circumstances that surrounded and motivated the composition of this poem and refer to earlier studies of the work. It will explore the discourses of religion, science, love, sexuality, space and time 
and the circulation of power implicit in the compass imagery used in this piece of literature.

Gallagher and Greenblatt (2001) note that the immense difficulty of defining New Historicism and delimiting its objects of study is that no "editorial statement ... staking out ... [their] theoretical position" was ever written for Representations (p. 4), the academic journal most closely associated with New Historicist studies. According to Fox-Genovese (1989), Representations "brings together historians and literary critics in a colorful carnival of cultural readings and thick descriptions” (p. 214). Abrams (1999) mentions a large number of other areas of critical theory that overlap with the aims of New Historicism: Marxist criticism, discourse analysis, deconstructive criticism, dialogic criticism and feminist criticism (pp. 183, 187). In addition to examining "traditional historical topics,” New Historicists focus on marginalized narratives and bring "issues concerned with private life into the foreground of [their] historical inquiry" (Tyson, 2006, pp. 288, 289). Despite this wide variety, both in terms of methodology and object of study, there are three defining concepts that underlie most New Historicist studies.

First, literary works are considered historical documents. This New Historicist "simultaneous obsession with history and art" echoes the ideas of Johann Gottfried von Herder (Gallagher \& Greenblatt, 2001, p. 6), an eighteenth-century German philosopher who wrote on many topics, including the philosophy of history (Forster, 2008, para. 1). Gallagher and Greenblatt (2001) write that Herder highlights the historical knowledge that poetry can impart:

In poetry's gallery of diverse ways of thinking, diverse aspirations, and diverse desires, we come to know periods and nations far more intimately than we can through the misleading and pathetic method of studying their political and military history. From this latter kind of history, we rarely learn more about a people than how it was ruled and how it was wiped out. From its poetry, we learn about its way of thinking, its desires and wants, the ways it rejoiced, and the ways it was guided either by its principles or its inclinations (pp. 6-7).

Here, Herder argues for the historical relevancy of poetry. New Historicists take this one step further and consider the literary value of historical narratives. Indeed, a central tenet of New Historicism is the "mutual 
embeddedness of art and history” (Gallagher \& Greenblatt, 2001, p. 7). New Historicist analyses of literary works, therefore, must consider the historical context in which the works were written as art does not occur in a vacuum and also must acknowledge that the literary discourse shapes as much as it is shaped by historical discourse and historical events. In short, art and history are both mutually constitutive.

Secondly, New Historicism views literary works as cultural artifacts. The analysis of these artifacts can shed light on the various discourses circulating at the time and place the literary works were written (Tyson, 2006, pp. 286-287). Discourses are particular to a given culture, and the intersection of various discourses creates what Geertz terms "webs of significance" (Geertz, 1994, p. 214). These discourses provide a context from which cultural artifacts can be subjected to "thick description" (p. 220): "a detailed description of the complex web of social relations that constitute a culture" (Martin \& McIntyre, 1994, p. 161). Let it be objected that present-day scholars' temporal and geographic distance from their objects of study might hinder their comprehension of cultural life distant from their own, Gallagher and Greenblatt (2001) note that a contemporary vantage point allows for the discovery of meanings that the authors themselves would not have been able to articulate: "something that the authors we study would not have had sufficient distance upon themselves and their own era to grasp" (p. 8). Bennett (2005) writes of this: "One of the characteristic gestures of Greenblatt's work, for example, is to link a canonical English text with a colonial practice, discourse, signifying system, or event of which the author of the canonical work was not, could not have been, aware" (p. 90).

Thirdly, New Historicists, relying on the works of Michel Foucault, see a circulation of power "in all directions, to and from all social levels, at all times" (Tyson, 2006, p. 284). Power should not be understood, as it has in "Western societies since the Middle Ages . . . [solely] in terms of law" (Foucault, 1978, p. 87). Rather, alternative sources and channels by which power circulates like "the exchange of ideas through the various discourses a culture produces” (Tyson, 2006, p. 284) must also be considered.

\section{JOHN DONNE'S A VALEDICTION: FORBIDDING MOURNING}

John Donne (1572-1631), an English poet and clergyman, is considered as the greatest of the metaphysical poets. He was born in 
London and grew up in a Roman Catholic family. In those years, Donne was subjected to discrimination by the Anglican majority. He later, however, joined the Anglican Church. In 1598, he was appointed secretary to Sir Thomas Egerton. In 1601, Donne's secret marriage to Egerton's sixteen-year-old niece Ann More, resulted in his brief imprisonment. From 1611 to 1612, he "accompanied Sir Robert Drury to France on a long diplomatic mission, during which he composed some of his most acclaimed verse letters, funeral poems, holy sonnets and love poems, in particular A Valediction: Forbidding Mourning" (Napierkowski, 1998, para. 3). He became the dean of Saint Paul's Cathedral in 1621 and dedicated the rest of his life to religious writings until his death in 1631 .

Pebworth (1989) divides Donne's literary output into two categories: those works printed (with Donne's knowledge) during the poet's lifetime and those works that circulated privately in manuscript to "individual recipients and/or to a coterie" (p. 61). With respect to this second group, these poems are "the product of a particular social context" (p. 71). Pebworth argues that an examination of the nature and purpose of coterie poetry of Donne's time may prove helpful as he attributes all the fundamental characteristics of Donne's poetry to its "coterie character" (p. 62). He reinforces his argument by bringing a quotation from Arthur F. Marotti:

His creation of a sense of familiarity and intimacy, his fondness for dialectic, intellectual complexity, paradox and irony, the appeals to shared attitudes and group interests (if not to private knowledge), the explicit gestures of biographical self-referentiality, the styles he adopted or invented all relate to the coterie circumstances of his verse (Pebworth, 1989, p. 62).

A Valediction: Forbidding Mourning was first published posthumously in 1633. It is a lyric poem written in nine four-line stanzas. The meter is iambic tetrameter and each stanza has the rhyme scheme of an alternating $\mathrm{ABAB}$. The poem uses ingenious metaphysical conceits to caution against mourning due to lovers' separation as their love is more of a spiritual one than a physical one.

This poem belongs to the second group of private or coterie poetry as it has been speculated that it was written specifically for Donne's wife, Anne More Donne, as the two were to experience a geographical 
separation while the author traveled to France on government business and his wife remained in England (Cummings, n.d., para. 3). Izaak Walton, Donne's contemporary, in his biographical book on John Donne writes: "the author gave these lines to his wife in 1611" (Rosenblum, 2002, para. 1). This poem, then, is a private document written not for mass circulation but for the eyes of the poet's wife or at most for a coterie. It belongs to Donne’s "occasional" poems written to "mark births, marriages, deaths, and other important events" (Pebworth, 1989, p. 64) or in this case "consoling a lover" (p. 65). Donne's motivation for writing this poem, therefore, can range from the expression of a personal feeling in the "tradition of the conge d'amour, a consolation when lovers part" (Rosenblum, 2002, para. 1) to achievement of "professional advancement" (Pebworth, 1989, p. 63) by writing coterie poetry, "not offering them in large numbers for sale to the vulgar, but giving them in limited numbers to members of his coterie, patrons, prospective patrons" (p. 64) as it was the case for aspirant poets in the Jacobean era (p. 62): "His poetry is not merely careerist in intent. But he was part of a coterie in which attitudes toward poetry were shaped by ambition, and his participation in that coterie surely affected his attitude toward poetry” (p. 63).

\section{DISCOURSES OF RELIGION, SCIENCE AND LOVE}

Donne (1987a) opens A Valediction: Forbidding Mourning with a simile which compares the death of virtuous men to the speaker's forthcoming separation from his lover: "As virtuous men pass mildly away, / And whisper to their souls to go" (ll. 1-2) and asks for the same quietude from his beloved for his departure: "So let us melt, and make no noise" (1. 5). In forming this unusual analogy, he makes use of the religious discourse of his time as it was believed that the pious would not fear death but would accept it with quiet demeanor:

In likening his departure to the deaths of "virtuous men,” he is making reference to the fact that pious men who are secure in their faith do not fear death. Rather, they embrace it, because they know that eternal life awaits them, and they will be welcomed by the arm of their Lord (Napierkowski, 1998, para. 17).

Donne is, then, quick to reject the Petrarchan discourse which idealizes the beloved as "untouchable and godlike" and to denounce the "philosophy 
that relies on such metaphors" (Rosenblum, 2002, para. 12): "No tearfloods, nor sigh-tempests move" (l. 6). He returns to his use of religious discourse in lines 7-8 where he considers such public demonstration of love a "profanation" which ruins the sanctity of their religion of love by revealing it to the "laity." This wish to "love privately" is in stark contrast to the "conventions of Renaissance love poetry, in which the lover wishes to broadcast his love to the world" (Napierkowski, 1998, para. 6).

In the third stanza, the poet contrasts the harmless "trepidation of the spheres” (a heavenly vibration) with destructive earthquakes (an earthly vibration) to differentiate between his and his lover's spiritual union and the physicality of "Dull sublunary lovers' love" (l. 13). In doing so, he chooses the Ptolemaic geocentric model of the universe over the Copernican heliocentric model of cosmos, proposed by Nicolaus Copernicus in the sixteenth century (Lindberg, 2003, p. 36), as "trepidation of the spheres" refers to the "vibration of the outermost sphere of the Ptolemaic universe, causing each sphere within to move accordingly" (Napierkowski, 1998, para. 8). This choice of Ptolemaic discourse is in line with the teachings of the Catholic Church which at the time considered the earth as the center of the universe and regarded scientists like Galileo Galilei (1564-1642) who supported the Copernican heliocentrism as heretics (Patrick, 2007, p. 539). The discourse of science is also present when Donne employs the gold simile to express the expansion of their love during the separation. Their souls ("which are one") can expand in order to accommodate physical distance rather than breaking apart: "Though I must go, endure not yet / A breach, but an expansion, / Like gold to airy thinness beat" (Donne, 1987a, ll. 22-24). Gold's scientific property of "malleability" parallels the "lovers' [emotional] ability to bend to circumstance yet keep each other spiritually close by virtue of their deep bond” (Bussey, 2001, para. 8). Finally, the compass and the circle imagery (which will be fully explored later in the paper) is very much related to the scientific discourse of Donne's time as Galileo "invented the mathematical compass (which figures centrally in . . . 'Valediction: Forbidding Mourning')” just two years prior (Napierkowski, 1998, para. 29).

Donne's concept of "higher union of their souls" is based on the "standard Renaissance philosophy of love. It is, in fact, a topos which includes a generic and metaphysical concept of love as a union of two souls in one" (Cirillo, 1969, p. 81). In addition to the direct reference to the merging of two souls in line 21 ("Our two souls therefore, which are one"), 
two other passages contain language specifically associated with this concept. Cirillo, following John Freccero, notes that the "term 'melt' was traditionally used to describe the blending of souls in love” (p. 86). Donne used precisely this term to describe his union with his wife: "So let us melt, and make no noise" (Donne, 1987a, l. 5). Later in the poem, he writes "But we, by a love . . . / Inter-assurèd of the mind" $(11.17,19)$. The meaning of the word "inter-assurèd" is not clear in modern English, and the word itself does not appear in the Oxford English Dictionary as an entry. However, its components do. The prefix "inter-" means "between or among themselves or one another; with each other; mutually, reciprocally, alternately," while "assured" most commonly means "made sure or certain." An obsolete meaning of "assured" is "engaged for marriage, betrothed." Donne's description of his and his wife's love as "inter-assured of the mind" would, therefore, indicate a marriage (or union) of their minds which echoes a concept formed in a line from his other poem "The Ecstasy:" "And by good love were grown all mind" (l. 23). That is, "the Neoplatonic idea of love: the soul's yearning after beauty” (Abrams, 1987, p. 602). Their love is so "refined, or purified of materiality [and physicality] . . . that their minds or souls fuse” (Cirillo, 1969, p. 91).

\section{THE COMPASS IMAGERY AND THE DISCOURSES OF SPACE AND TIME}

The image of the compass appears in line 26 of the poem: "If they be two, they are two so / As stiff twin compasses are two" (Donne, 1987b, ll. 25-26). As a compass is used primarily to draw circles, it bears examining the meaning of circles in Donne's culture. The image of the circle has resonated with many thinkers and writers throughout the ages. Freccero (1963) notes that "For Dante, as for most thinkers of his time, the spatial and temporal perfection represented by the circle precluded its use as a symbol for anything human” (p. 335).

Gorton (1998) in her essay, "John Donne’s Use of Space,” explains one of the dominant ideas of the cosmos in operation during Donne's time:

The cosmos was centred upon earth and arranged in concentric spheres. The sphere enclosed by the orbit of the moon was called the sublunary sphere and the sphere above it, the celestial sphere. In the sublunary sphere everything was always becoming something else, 
living and dying, but the celestial sphere was made from better, purer, simpler stuff than the sublunary sphere, and the heavenly bodies lasted for all time (para. 6).

The purity of the celestial realm was, supposedly, linked to the "circular motion" of heavenly bodies. As Donne uses the image of the compass in reference to his union with his wife, it begs the question: Did Donne consider this union a heavenly union, a human union, or some mixture of the two?

In contrast to celestial objects, sublunary objects, or objects that occupied the space delimited by the moon's orbit, followed "rectilinear motion." These objects were comprised of the "four elements of earth, water, air and fire” (para. 6).These characteristics are certainly present in Donne’s (1987a) A Valediction: Forbidding Mourning:

Dull sublunary lovers' love

(Whose soul is sense) cannot admit

Absence, because it doth remove

Those things which elemented it (ll. 13-16).

Here, Donne specifically contrasts his relationship with "sublunary" relationships. These latter types cannot withstand physical separation because their very existence is predicated on physicality and the five senses. Donne considers his own relationship far superior as it is predicated on a transcendent spiritual connection.

In considering the spatial aspect of the circle, it would seem that Donne was indeed arguing that his relationship with his wife was divine. However, the perfect circles of the celestial sphere do not only encapsulate space; they also have a temporal aspect. Gorton (1998) notes that there is a "long tradition associating . . . circles" with "eternity" (para. 25) and a sense of timelessness, as heavenly bodies were supposed to move "for all time in a regular pattern” (para. 6). Indeed, in one of his sermons, Donne describes his concept of circles and eternity:

... for immortality, and eternity is a Circle too; not a Circle where two points meet, but a Circle made at once; This life is a Circle, made with a Compasse, that passes from point to point; That life is a Circle stamped with a print, an endlesse, and perfect Circle, as soone as it begins (Donne \& Keynes, 1923, p. 3). 
The image presented in A Valediction: Forbidding Mourning is the second type of circle which belongs to "this life" and is made with a "compass." At the end of the poem, Donne writes that the stability of the fixed leg of the compass "makes me end where I begun" (1. 36). Here, Donne's circle is created by the joining of two points, the beginning and the ending: it is a circle that is created through time. Time, then, is a human condition. The heavenly circle, however, is "not a Circle where two points meet"-it exists outside the boundaries of time. The compass imagery in $A$ Valediction: Forbidding Mourning, therefore, is not attributing divine characteristics to the spiritual melding of the lovers' souls. The relationship remains human as it is bound by temporality. As this relationship is human, it necessarily involves physicality, not only a spiritual union.

\section{DISCOURSE OF SEXUALITY}

Thus far, the discussion of love has focused entirely on the spiritual realm, souls divorced from their human bodies, but in Donne's poem, the physical is surely present. For instance, Donne mentions "eyes, lips and hands" (l. 20). Reading "with the grain" (to "interpret the work the way it seems to invite us to") (Tyson, 2006, p. 7), one could argue that the mentioning of these body parts is specifically to note that due to the solidity of the spiritual side of the relationship, its physical aspects will not be missed. Reading "against the grain", however, (to "analyze elements in the text of which the text itself seems unaware") (p. 7), the reader might ask, "If these aspects are not that important, why are they even mentioned?" Indeed, the sheer fact that these body parts are enumerated reveals that the physical separation was on Donne's mind, and therefore of concern for him and his wife. Furthermore, the language that the poet uses in the last three stanzas is very suggestive ("stiff," "erect," "firmness," "come”) and may contain some sexual innuendos:

Line 26, with its earlier description of the "stiff twin compasses," may also hint at the man's erection. The speaker may be indulging in further punning by describing how the compass, when closing, "comes home," a common expression for "reaching the target," which might suggest sexual intercourse (Napierkowski, 1998, para. 13).

The word "erect" is perhaps the most disputed and ambiguous word in the poem: "It leans, and hearkens after it, / And grows erect, as that comes 
home" (ll. 31-32). The first "it" is referring to the fixed leg of the compass. Does the word "erect" belong solely to the domain of scientific discourse, or does it contribute to the discourse of sexuality?

With reference to the realm of scientific discourse, these lines describe the angle between the two legs of the compass. With a circle of a larger circumference, the fixed part of the compass would give the impression of leaning, as the angle between the two parts of the compass increases in relation to the circle's circumference. With a smaller circle, the distance between the two parts of the compass is similarly smaller, and the fixed part of the compass gradually approaches vertical ("erect") as the speaker "comes home" and stands side by side with his lover like the "two legs of a closed compass" (Bussey, 2001, para. 10). John Freccero (1963), for one, would rather take these lines primarily "geometric," as it "has the advantage of doing violence neither to the poem nor to its context" (p. 350). The violence to which Freccero refers would, hypothetically, be the result of an erotic interpretation of these lines, specifically the word "erect." It is unclear what Freccero means by the "context:" the poem dates from a time when explicit sexual discourse was not uncommon:

At the beginning of the seventeenth century a certain frankness was still common, it would seem. Sexual practices had little need of secrecy; words were said without undue reticence, and things were done without too much concealment; one had a tolerant familiarity with the illicit. Codes regulating the coarse, the obscene, and the indecent were quite lax ... It was a time of direct gestures, shameless discourse [my emphasis], and open transgressions.

(Foucault, 1978, p. 3).

Furthermore, if the poem is to be considered Donne's expression of a personal feeling to his wife, a little sexual teasing while emphasizing their spiritual union is not at all far-fetched. As such, the erotic connotations of "erect" should be admitted into the possibilities of interpretation for the poem.

\section{CIRCULATION OF POWER IMPLICIT IN THE COMPASS IMAGERY}

Conceiving of power in the manner of Foucault, particularly with respect to the circulation of power in sexual relations, allows for a more 
nuanced view of the relationship presented in A Valediction: Forbidding Mourning. Foucault writes that "relations of power" are "immanent" with regard to "sexual relations" and that "they are the immediate effects of the divisions, inequalities, and disequilibriums" that occur in the sexual relations (p. 94).

The manner in which Donne relates the various parts of the compass to himself and his wife reveals these divisions and inequalities. Donne's leg of the compass moves freely and "far doth roam" (1. 30). His wife, however, is described as being "the fixed foot" of the compass which "... makes no show / To move, but doth, if th' other do (ll. 27-28) and "leans and hearkens after" (1. 31) the other leg. Her movements are, thus, directly influenced by her husband's movements. With this description, Donne reinscribes the stereotypical gender associations of his time and the assumption that the male in the relationship controls the actions of the female. The woman, his wife, remains confined to one geographic location, the home. And though her position (or angle) may change, she is essentially tied to this one spot while the man, Donne, can travel virtually at his leisure.

At the same time, Donne's use of language calls into question certain binary oppositions of the masculine and feminine. In reference to exactly this point, Meakin (1998) cautions that "It is . . not always illuminating to 'fix' the connotations of words and apply them across the boundaries of the individual poem, for the gender positions associated with certain binarisms are not always predictable in Donne's poetry" (p. 59). Meakin points to "fixed foot" and "firmness" as words typically signifying masculine identity but which are associated with the female subject in A Valediction: Forbidding Mourning (p. 59). These sexual reversals (the word "erect" which is attributed to the "fixed foot" is another instance), in fact, illustrate how power circulates oppositely from those described in the preceding paragraph. Here, it is the actions of the woman (remaining steady and chaste) that allow the man to return home safely. Thus, as the title of the poem indicates, the woman must not mourn the departure of his man; she must instead be the pillar of strength which makes his safe return possible.

\section{CONCLUSION}

To conclude, the multiplicity of possible interpretations makes this particular poem subject to much debate. Donne offers heavenly images alongside earthly ones, sexist stereotypes alongside feministic concepts which are all present and valid. Corthell (1997), in his book, Ideology and 
Desire in Renaissance Poetry: The Subject of Donne, which has a chapter named, "Donne's New Historicism and the Practice of Satire," argues that a New Historicist "rereading of Donne’s texts" "can help us understand why we tend to construct 'culture' as a poetic text” (pp. 18-19) and how his poems can come to be "the representation of the Renaissance in literary history” (p. 113). Thus, the examination of the various discourses operating in the poem (from the religious and scientific discourses to the fusion of discourses of spirituality and sexuality) allows A Valediction: Forbidding Mourning to speak so much about the culture in which it was written.

\section{REFERENCES}

Abrams, M. H. (Ed.). (1987). The Norton anthology of English literature (5th ed.). New York: W. W. Norton \& Company.

Abrams, M. H. (1999). A glossary of literary terms (7th ed.). Boston: Heinle \& Heinle.

Bennett, A. (2005). The author. New York: Routledge.

Bussey, J. (2001). An overview of imagery in Donne's poem. In M. R. Napierkowski (Ed.), Poetry for students. Retrieved May 28, 2009, from http://www.enotes.com/valediction-forbidding/an-overview-imagerydonnes-poem

Cirillo, A. R. (1969). The fair hermaphrodite: Love-union in the poetry of Donne and Spenser. Studies in English Literature, 1500-1900, 9(1), 81-95.

Corthell, R. (1997). Ideology and desire in renaissance poetry: The subject of Donne. Detroit, Mich.: Wayne State University Press.

Cummings, M. J. (n.d.). A valediction: Forbidding mourning. Retrieved May 21, 2009, from http://www.cummingsstudyguides.net/Guides3/Valediction. html\#Top

Donne, J. (1987a). A valediction: Forbidding mourning. In M. H. Abrams (Ed.), The Norton anthology of English literature (5th ed., pp. 600-601). New York: W. W. Norton \& Company.

Donne, J. (1987b). The ecstasy. In M. H. Abrams (Ed.), The Norton anthology of English literature (5th ed., pp. 601-604). New York: W. W. Norton \& Company.

Donne, J., \& Keynes, G. (1923). X sermons: Preached by that late learned and Rev. Divine John Donne. London: The Nonesuch Press.

Forster, M. (2008). Johann Gottfried von Herder. In The Stanford encyclopedia of philosophy. Retrieved May 24, 2009, from http://plato.stanford.edu/ archives/fall2008/entries/herder/ 
Foucault, M. (1978). The history of sexuality (Vol. 1). (R. Hurley, Trans.). New York: Pantheon.

Fox-Genovese, E. (1989). Literary criticism and the politics of the New Historicism. In H. A. Veeser (Ed.), The new historicism (pp. 213-224). New York: Routledge.

Freccero, J. (1963). Donne’s Valediction: Forbidding mourning. ELH, 30(4), 335376.

Gallagher, C., \& Greenblatt, S. (2001). Practicing new historicism. Chicago: University of Chicago Press.

Geertz, C. (1994). Thick description: Toward an interpretive theory of culture. In M. Martin, \& L. C. McIntyre (Eds.), Readings in the philosophy of social science (pp. 213-232). Cambridge, Massachusetts: MIT Press.

Gorton, L. (1998, September). John Donne's use of space. Retrieved June 28, 2009, from http://purl.oclc.org/emls/04-2/gortjohn.htm

Lindberg, D. C. (2003). Galileo, the church, and the cosmos. In D. C. Lindberg, \& R. L. Numbers (Eds.), When science \& christianity meet (pp. 33-60). Chicago Press: University of Chicago Press.

Martin, M., \& McIntyre, L. C. (1994). Interpretation and meaning. In M. Martin, \& L. C. McIntyre (Eds.), Readings in the philosophy of social science (pp. 157-162). Cambridge, Massachusetts: MIT Press.

Meakin, H. L. (1998). John Donne's articulations of the feminine. New York: Oxford University Press.

Napierkowski, M. R. (Ed.). (1998). A valediction: Forbidding mourning. In Poetry for students. Retrieved May 28, 2009, from http://www.enotes.com/ valediction-forbidding

Patrick, J. (2007). Renaissance and reformation. New York: Marshall Cavendish.

Pebworth, T. L. (1989). John Donne, coterie poetry, and the text as performance. Studies in English Literature, 1500-1900, 29(1), 61-75.

Rosenblum, J. (2002). A valediction: Forbidding mourning. In Masterplots II: Poetry, revised edition. Retrieved May 21, 2009, from http://www.enotes. $\mathrm{com} /$ valediction-forbidding-salem/

Tyson, L. (2006). Critical theory today (2nd ed.). New York: Routledge. 